\title{
Control of Urochloa brizantha cv. Marandu by Glyphosate and its Interaction with light availability
}

The use of glyphosate in the desiccation of Urochloa brizantha cv. Marandu is a common practice in Brazilian agriculture; however, the effect of night application in this species is not clearly known. Thus, this study aimed to evaluate the influence of light availability on glyphosate efficiency in the control of $\mathrm{U}$. brizantha. Seven herbicide doses $(0,90,180,360,720,1,440$, and 2,160 g ha-1) in plants submitted to daytime application, followed by 24,48 , or $72 \mathrm{~h}$ of dark and night were evaluated. The accumulation of dry matter of $U$. brizantha, the visual evaluation of injuries, the doses that provided 50 and $80 \%$ of control (C50 and C80), and the doses that provided 50 and $80 \%$ reduction of dry matter (GR50 and GR80) at 7, 14, 21, 28 days after application (DAA) and at 30 days after cutting (regrowth) were determined. Satisfactory control (>80\%) and the absence of regrowth were established from $1,440 \mathrm{~g}$ ha- 1 in all treatments. However, injury reduction was observed in plants that remained $72 \mathrm{~h}$ in the dark relative to daytime treatment in all doses. The highest dose of glyphosate $(2,160 \mathrm{~g}$ ha-1) reduced $\mathrm{U}$.brizantha by 41,15 , and $3 \%$. For the dose of $1,440 \mathrm{~g}$ ha- 1 the reduction was 37,16 , and $6 \%$, at 7, 14, and 21 DAA, respectively. The values of GR50 and GR80 decreased from regrowth ( 37 and $28 \%$ less relative to daytime treatment) for plants that were $72 \mathrm{~h}$ in the dark. The light favors the behavior of glyphosate in the plant, and therefore this herbicide should not be applied at night for the control of $U$. brizantha.

Keywords: Injury level; Reduction of dry matter; Night application; Regrowth.

\section{Controle de Urochloa brizantha cv. Marandu por Glifosato e sua interação com a disponibilidade de luz}

\begin{abstract}
O uso do glifosato na dessecação de Urochloa brizantha cv. Marandu é uma prática comum na agricultura brasileira; entretanto, o efeito da aplicação noturna nesta espécie não é claramente conhecido. Assim, este trabalho teve como objetivo avaliar a influência da disponibilidade de luz na eficiência do glifosato no controle de U. brizantha. Foram avaliadas sete doses de herbicida (0,90, 180, 360, 720, 1.440 e $2.160 \mathrm{~g}$ ha-1) em plantas submetidas à aplicação diurna, seguidas de 24,48 ou 72 horas de escuridão e noite. $\mathrm{O}$ acúmulo de matéria seca de U. brizantha, a avaliação visual das injúrias, as doses que proporcionaram 50 e $80 \%$ de controle (C50 e C80), e as doses que proporcionaram 50 e 80\% de redução da matéria seca (GR50 e GR80) aos 7, 14, 21, 28 dias após a aplicação (DAA) e aos 30 dias após o corte (rebrota). O controle satisfatório (> 80\%) e a ausência de rebrota foram estabelecidos a partir de $1.440 \mathrm{~g}$ ha-1 em todos os tratamentos. No entanto, a redução do dano foi observada em plantas que permaneceram $72 \mathrm{~h}$ no escuro em relação ao tratamento diurno em todas as doses. A maior dose de glifosato (2.160 g ha-1) reduziu U brizantha em 41,15 e $3 \%$. Para a dose de $1.440 \mathrm{~g}$ ha-1 a redução foi de 37,16 e $6 \%$, aos 7,14 e 21 DAA, respectivamente. Os valores de GR50 e GR80 diminuíram com a rebrota ( 37 e $28 \%$ menos em relação ao tratamento diurno) para plantas que ficaram $72 \mathrm{~h}$ no escuro. A luz favorece o comportamento do glifosato na planta, portanto este herbicida não deve ser aplicado à noite para o controle da U. brizantha.
\end{abstract}

Palavras-chave: Nível de lesão; Redução de matéria seca; Aplicação noturna; Recrescimento.

Larissa Martins Mota (iD

Universidade Federal de Viçosa, Brasil

http://lattes.cnpq.br/0612967728315429

http://orcid.org/0000-0001-8931-8717

larissa.m.mota.rm@gmail.com

Maura Gabriela da Silva Brochado (iD)

Universidade Federal de Viçosa, Brasil

http://lattes.cnpq.br/1509312557137003

http://orcid.org/0000-0003-1981-121X

maurabrochado@gmail.com

Adalin Cezar Moraes de Aguiar (iD

Universidade Federal de Viçosa, Brasil

http://lattes.cnpq.br/0435751423360470

http://orcid.org/0000-0003-1138-8197

adalin-cezar@hotmail.com

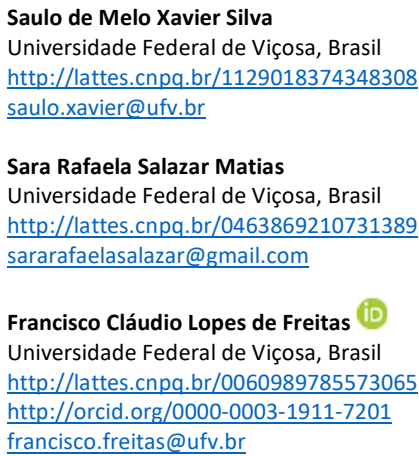

Kassio Ferreira Mendes (iD

Universidade Federal de Viçosa, Brasil http://lattes.cnpq.br/7101423608732888 http://orcid.org/0000-0002-2869-8434 kfmendes@ufv.br

\section{Referencing this:}

MOTA, L. M.; BROCHADO, M. G. S.; AGUIAR, A. C. M.; SILVA, S. M. X.; MATIAS, S. R. S.; FREITAS, F. C. L.; MENDES, K. F.. Control of Urochloa brizantha cv. Marandu by Glyphosate and its Interaction with light availability. Revista Ibero Americana de Ciências Ambientais, v.12, n.6, p.130-139, 2021. DOI: http://doi.org/10.6008/CBPC21796858.2021 .006 .0011 


\section{INTRODUCTION}

The environmental conditions during the application of an herbicide may favor or disadvantage several stages of herbicide-plant interaction, highlighting the interception, absorption, and translocation of the product by the plant (CIESLIK et al., 2013; ALMEIDA, 2020). One of the herbicides widely used in nocturnal periods is glyphosate. Although this practice is common, it is not yet known why the time of application interferes with the control efficacy of plants (MARTINSON et al., 2002; WALTZ et al., 2004; MOHR et al., 2007; SANTOS JUNIOR et al., 2013).

The herbicide must penetrate the plant and be translocated to the target sites to present its phytotoxic effect (SATCHIVI et al., 2000). Glyphosate moves in phloem following the route of photosynthesis products, from photosynthetically active leaves (source) towards the growing plant parts (drain); thus, herbicide absorption, translocation, and metabolism can affect the sensitivity of a plant, as it needs to reach the site of action at an appropriate concentration (HETHERINGTON et al., 1999; CAMPOS et al., 2013).

The availability of sunlight is a factor that directly affects photosynthesis, as well as the amount of sugar translocated in the plant, which also influences herbicide movement. Therefore, conditions that favor photosynthesis can also aid in the behavior of glyphosate (DELLA-CIOPPA et al., 1986; ROMAN et al., 2007). In a study conducted by Vidal et al. (2014), in which they evaluated the environmental factors that affect the efficacy of glyphosate, it was seen that factors such as temperature, relative humidity, soil, radiation availability of nutrients, nutritional status of plants, and the occurrence of rain after application of the product, as well as the interaction between the environment and the morphological and phenological characteristics of the plants may favor or affect the application of this herbicide.

One of the most common uses of glyphosate is in the desiccation of cover crops or spontaneous vegetation for subsequent sowing of the crop.Plants belonging to the genus Urochloa are widely used as soil cover and are considered excellent tropical forage (FREITAS et al., 2005). These plants are efficiently controlled in a few days after herbicide application, being suitable for straw formation for the no-tillage system (BORGHI et al., 2008; SILVA et al., 2013).

Factors such as light radiation play a key role in the metabolic pathway of some products, and it is a factor that is absent at night. Therefore, understanding the role of sunlight in the activity of this herbicide is important to assist the producer in choosing the best spray time. Therefore, this study aimed to determine the efficiency of glyphosate in the control of Urochloa brizantha cv.Marandu through dose-response curves depending on the availability of sunlight.

\section{MATERIALS AND METHODS}

\section{Plant material and growth conditions}

Seeds of Urochloa brizantha cv.Marandu were sown in polyethylene trays of 200 cells containing commercial substrate composed of pine bark, vermiculite, PG mix 14:16:18, potassium nitrate, simple superphosphate, and peat (Tropstratum $\mathrm{HT}^{\circ}$, supplier, local). Three seeds were deposited per cell to avoid 
germination failures, and subsequently thinning was performed leaving only one plant per cell. Fifteen days after planting, fertilization was performed with $8 \mathrm{~g} \mathrm{~L}^{-1}$ ammonium sulfate and $3 \mathrm{~g} \mathrm{~L}^{-1}$ monopotassium phosphate at $60 \mathrm{~mL}$ per tray. The trays were kept in a greenhouse, with an average temperature of $26^{\circ} \mathrm{C}$, relative humidity at $70 \%$, and a photoperiod of $12 \mathrm{~h}$ while under irrigation by micro-sprinklers.

The seedlings were transplanted to pots of $6 \mathrm{dm}^{3}$ filled with Oxisol (Latossolo Vermelho Amarelo) from Viçosa, Minas Gerais, Brazil, corrected and fertilized with $600 \mathrm{~g}$ super simple phosphate granulated, 300 g NPK 8-28-16, $200 \mathrm{~g}$ limestone for every $210 \mathrm{~L}$ of soil, according to soil analysis and recommendation for $U$. brizantha, 30 days after planting in trays.

The vessels were kept in the greenhouse, where pruning was performed 30 days after transplantation and another fertilization with $3 \mathrm{~g} \mathrm{~L}^{-1}$ of monopotassium phosphate and $8 \mathrm{~g} \mathrm{~L}^{-1}$ of ammonia sulfate, $70 \mathrm{~mL}$ per pot. Subsequently, the plants were left open for approximately 70 days, for acclimatization and rustification of the species. Two fertilizations were performed in this period: one on day 65 , and the other on day 70 . In the first, each pot received $100 \mathrm{~mL}$ of the nutrient solution, and in the second fertilization, each plant received $10 \mathrm{~g}$ of $20-05-20$ formulated NPK.

\section{Glyphosate application}

Seven doses of glyphosate $\left(0,90,180,360,720,1,440\right.$ and 2,160 $\left.\mathrm{g} \mathrm{ha}^{-1}\right)$ and five light availability levels relative to glyphosate spraying were evaluated: daytime application, in which the plants were sprayed with glyphosate in the daytime; application followed by 24,48 or $72 \mathrm{~h}$ of dark, in which the plants were sprayed with glyphosate, and later were submitted to the dark in the different periods as well as night application, in which plants were sprayed with glyphosate at night.

The treatments were arranged in a $7 \times 5$ factorial scheme (doses and light conditions), with four replications; therefore, there were 140 vessels containing $U$. brizantha, in which each experimental unit was composed of one plant.

The herbicide was applied wherein a costal spray was used pressurized by $\mathrm{CO}_{2}$ with constant pressure. The sprayer was equipped with a bar with two fan TTI 11002 type tips, spaced at $0.5 \mathrm{~m}$, with 250 $\mathrm{kPa}$ of pressure and a volume of syrup corresponding to $142 \mathrm{~L} \mathrm{ha}^{-1}$. The spray bar was maintained at a height of $50 \mathrm{~cm}$ from the plants. At daytime application, the temperature was $22.3^{\circ} \mathrm{C}$, the relative humidity was $73 \%$, and the wind speed was $4.5 \mathrm{~km} \mathrm{~h}^{-1}$; during the nighttime application, the ambient temperature was $21.5^{\circ} \mathrm{C}$, the relative humidity was $78 \%$ and the wind speed was $1.2 \mathrm{~km} \mathrm{~h}^{-1}$.

To simulate nighttime, the plants treated with the herbicide were placed in a closed environment coated with black plastic canvas. The vessels remained in this environment for 24,48 , and $72 \mathrm{~h}$, and were subsequently removed and kept back in the open in normal light conditions, where they remained until the end of the evaluations.

\section{Herbicide efficacy}

The percentage of plant injury was evaluated at $7,14,21$, and 28 days after the application (DAA) of 
glyphosate. The level of injury was quantified by visual evaluation, assigning scores relative to the control treatment, without herbicide application, being considered $0 \%$ the absence of symptoms and $100 \%$ the total death of the plant (SBCPD, 1995). The regrowth capacity of the plants was evaluated by pruning at 30 DAA and the last visual evaluation was performed 30 days after cutting the plants.

The plants were cut close to the ground, packed in paper bags, and placed in a greenhouse (FANEM, model 320-SE, São Paulo, Brazil) with forced air circulation (65 \pm 3 으) until reaching the constant mass. Subsequently, the dry matter mass of the aerial part was determined with the aid of a precision scale (SHIMADZU, model AY220). The dry matter mass was corrected for percentage values, considering the mass of plants that did not receive the herbicide, as $100 \%$ biomass.

\section{Statistical analysis}

The data were analyzed using the $F$ test of variance analysis (ANOVA), performed in software $R^{\circ}$, version 3.6.1 (R CORE TEAM, 2019), to verify the significance of factor interaction. When significant $(p \leq 0.05)$, the data were analyzed with the aid of log-logistic nonlinear regressions using SigmaPlot ${ }^{\circledR}$ software (version 12.5 for Windows, Systat Software Inc., Point Richmond, CA, USA).

The variable level of control injury was adjusted to the model proposed by Streibig et al. (1988) according to equation 1 :

$$
y=\frac{a}{\left[1+\left(\frac{x}{b}\right)^{c}\right]}
$$

in which $y=$ percentage of control, $x=$ herbicide dose, and $a, b$, and $c=$ curve parameters, so that $a$ is the difference between the maximum and minimum point of the curve, $b$ is the herbicide dose that provides $50 \%$ response of the variable and $c$ is the slope of the curve.

For the dry matter variable, the model proposed by Seefeldt et al. (1995) was adopted, according to equation 2:

$$
y=a+\frac{b}{\left[1+\left(\frac{x}{c}\right)^{d}\right]}
$$

in which: $y=$ residual percentage of dry mass, $x=$ herbicide dose, and $a, b, c$, and $d=$ curve parameters, so that $a$ is the lower limit of the curve, $b$ is the difference between the maximum and minimum point of the curve, $c$ is the herbicide dose that provides $50 \%$ response of the variable, and $d$ is the slope of the curve.

The calculation of the herbicide dose that provided 50 and $80 \%$ control ( $C_{50}$ and $C_{80}$, respectively) or 50 and $80 \%$ of dry matter reduction ( $\mathrm{GR}_{50}$ and $\mathrm{GR}_{80}$, respectively) of the plants was normalized by adjusting the regression equation.For this, as proposed by Carvalho et al. (2005), the inversion of the log-logistic model was opted for, leaving it as a function of $y$. Thus, using equation 3 it was possible to determine the $C_{50}$ or $C_{80}$ and using equation 4 to determine the $\mathrm{GR}_{50}$ or $\mathrm{GR}_{80}$, replacing y by the values 50 or 80 , respectively:

$$
\begin{aligned}
& x=b * \sqrt[c]{\frac{a}{y}-1} \\
& x=c * \sqrt[d]{\frac{b}{y-a}-1}
\end{aligned}
$$

\section{RESULTS AND DISCUSSION}

The factorial interaction between the availability of sunlight and the level of injury was significant at 
7 DAA ( $F=11.32, p<0.05), 14$ DAA ( $F=4.12, p<0.05)$, and 21 DAA $(F=3.76, p<0.05)$. The dry matter (regrowth) of the plants differed according to the availability of sunlight $(\mathrm{F}=5.17, p<0.05)$.

In general, for all luminosity conditions, the responses at the level of injury varied increasingly with the increase in the herbicide dose. Symptoms of plant injuries caused by glyphosate were apparent from the third to the fifth day after treatment; initially, chlorosis of the meristematic tissue occurs and plant growth is paralyzed, then progressive necrosis of the new to old tissue occurs (MARCHI et al., 2008). Grasses exposed to sublethal doses of glyphosate exhibit a chlorotic band through leaves in the verticil of the plant (PETERSON et al., 2001).

In the first evaluation (at $7 \mathrm{DAA}$ ), it was not yet possible to observe an injury level in $U$. brizantha above $80 \%$ [considered "very good" on the ALAM scale (1974)] in any of the treatments, and the maximum values were $74 \%$ and $72 \%$ for the highest dose of glyphosate $\left(2,160 \mathrm{~g} \mathrm{ha}^{-1}\right)$ in treatments with daytime and nocturnal application, respectively (Figure 1). The plants that remained under dark for $72 \mathrm{~h}$ presented a low level of injury for all doses, and even at the highest dose $\left(2,160 \mathrm{~g} \mathrm{ha}^{-1}\right)$ of glyphosate, the control of the plants was only $33 \%$ (Figure 1 ).

At 14 DAA, the symptoms caused by the herbicide increased in all treatments. However, it was still possible to notice differences; plants submitted to 48 and $72 \mathrm{~h}$ of dark, even at a dose of 2,160 $\mathrm{g} \mathrm{ha}^{-1}$, did not reach $80 \%$ in the level of injury (Figure 1 ).

At 21 DAA, the difference in control between treatments was reduced; however, it was still possible to notice that the plants that were $72 \mathrm{~h}$ in the dark still differed from the other treatments, presenting lower control values. In all other treatments, the level of injury exceeded $60 \%$ in the dose $360 \mathrm{~g} \mathrm{ha}^{-1}$ of glyphosate, but in this same dose, the plants that remained in the dark for $72 \mathrm{~h}$ presented only $46 \%$ of injury. However, from $1,440 \mathrm{~g} \mathrm{ha}^{-1}$ of the herbicide, the plants presented more than $80 \%$ injury, as well as in all other treatments (Figure 1)

In the results of the last evaluation (at $28 \mathrm{DAA}$ ) it was possible to observe that the five treatments have very similar behavior (Figure 1 ). Control was found above $80 \%$ of $U$. brizantha plants at doses $720,1,440$, and 2,160 $\mathrm{g} \mathrm{ha}^{-1}$ for all lighting conditions. In the research of Silva et al. (2013), U. brizantha, which was sowing in the field and sprayed at 230 days after sowing, at the end of 28 DAA presented, for doses $720,1,440$ and $2,160 \mathrm{~g} \mathrm{ha}^{-1}, 50 ; 62.5$ and $81.2 \%$ control, respectively. Thus, it is important to emphasize that the sensitivity of the cover plants to glyphosate varies according to the stage of development.

In this study, the absence of light in the first days for some treatments was a stress factor for the plant, especially in the first evaluations. Cataneo et al. (2003) stated that many herbicides have reduced action if the plant is under stress before, at the time, or hours after application, as they are less translocated and, consequently, are more available for metabolization, conjugation, or entrapment reactions. Since glyphosate is a systemic product, satisfactory plant control should be associated not only with the absorbed quantity but with the success of herbicide translocation (MARTINS et al., 2009).

Knowing that the efficient translocation of the product in the plant is of great importance, reduced absorption and/or translocation are often cited as the cause of tolerance or selectivity in numerous crops 
and weeds (CONCENÇO et al., 2007). If the sugars are not being produced and transported, the transport in phloem is decreased and, consequently, the herbicide does not translocate in the plant, becoming concentrated in the leaves (ROMAN et al., 2007). Thus, the results found indicate that the difference in the level of injury up to 21 DAA between treatments may have been due to changes in absorption and translocation.Added to this, because the leaves of $U$. brizantha are densely hairy, it makes it difficult to absorb the herbicide by cuticle and also by the low octanol content-water partition coefficient (log $\left.\mathrm{K}_{\mathrm{ow}}\right)(\sim$ $-4)$ of glyphosate compared to other herbicides (CASTRO et al., 2016; MOTA et al., 2020).
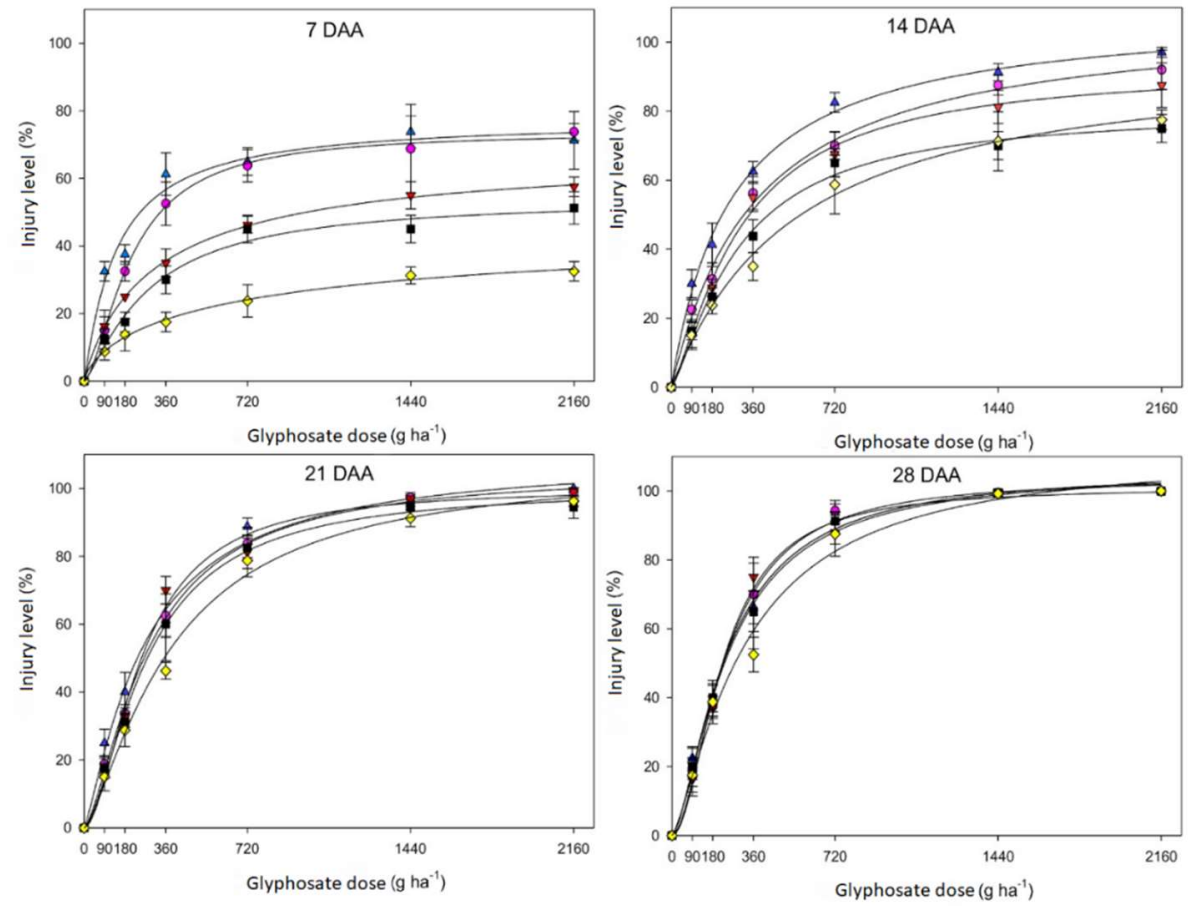

$\Delta$ Night

Daytime

$24 \mathrm{~h}$

$48 \mathrm{~h} \diamond 72 \mathrm{~h}$

Figure 1: Control (\%) by Urochloa brizantha cv.Marandu with glyphosate application (0, 90, 180, 360, 720, 1,440 and $\left.2,160 \mathrm{~g} \mathrm{ha}^{-1}\right)$ in the five availability of light with daytime, night application and followed by 24,48 , or $72 \mathrm{~h}$ of dark, with evaluation at 7, 14, 21 and 28 days after application (DAA) of the herbicide. The vertical bars on each symbol represent the standard deviation of the mean $(n=4)$.

Dry matter evaluations showed that in all luminosity conditions there was an effective reduction of $U$. brizantha plants, with a total absence of regrowth at the highest doses $\left(1,440\right.$ and $\left.2,160 \mathrm{~g} \mathrm{ha}^{-1}\right)$ and a reduction of more than $80 \%$ from the dose $720 \mathrm{~g} \mathrm{ha}^{-1}$ of glyphosate (Figure 2). At the lower doses, the control cannot be considered efficient, resulting in regrowth of the treated plants, a justifiable fact because they are lower doses than those recommended for $U$. brizantha plants in the advanced development stage and quite profiled (in this study, about 120 days after emergence) (Figure 2).

At 7 DAA, the plants that received spraying at night and daytime presented lower $C_{50}$ values $(247.94$ and $336.88 \mathrm{~g} \mathrm{ha}^{-1}$, respectively) when compared with plants that remained 24,48 , and $72 \mathrm{~h}$ under dark (985.66; 2,026.56 and >2,160 $\mathrm{g} \mathrm{ha}^{-1}$, respectively).

Similarly, at 14 DAA, the $C_{50}$ values of plants submitted to several hours of dark were higher when compared with the dose needed to produce the same effect on plants applied during the day $(1.07,1.34$, and 1.78 times higher for 24,48 , and $72 \mathrm{~h}$, respectively). At $21 \mathrm{DAA}$, the plants of $U$. brizantha submitted to $72 \mathrm{~h}$ 
of dark still have higher values of $\mathrm{C}_{50}$; however, the ratio of application of the daytime period and $24 \mathrm{~h}$ of dark reduced from 1.78 to 1.33 (25\%). However, in the last evaluation, at 28 DAA, the difference of $C_{50}$ between treatments was greatly reduced.

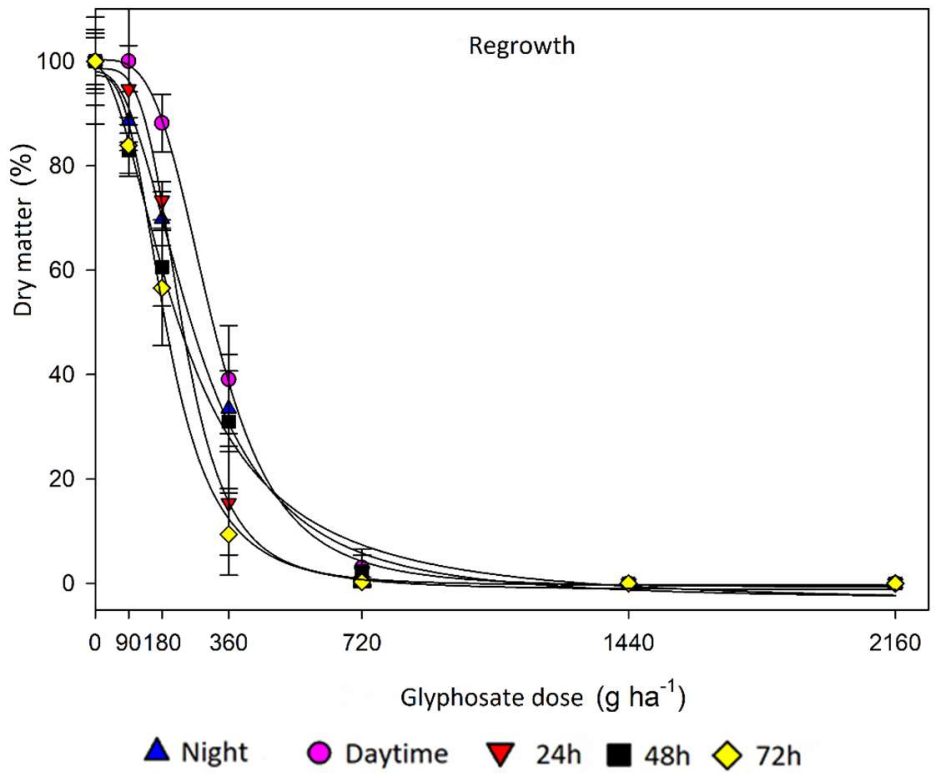

Figure 2: Dry matter reduction (\%) by Urochloa brizantha cv.Marandu with glyphosate application (0, 90, 180, 360, $720,1,440$ and $2,160 \mathrm{~g} \mathrm{ha}^{-1}$ ) in the five availability of light with daytime, night application and followed by 24,48, or 72 $\mathrm{h}$ of dark, with evaluation 30 days after cutting (regrowth). The vertical bars on each symbol represent the standard deviation of the mean $(n=4)$.

With this behavior, the treatments were equal to the end of the evaluations. In Table 1, a difference of up to $37 \%$ between treatments at 7 DAA in parameter $a$ can be observed, which represents the difference between the maximum and minimum point of the curve; however, this difference in the values found reduces over time, reaching $9 \%$ at the end of the $28 \mathrm{DAA}$, corroborating the behavior of the curves.

Similar values of curve slope (parameter $c$ ) from 7 to 28 DAA indicated that the curves presented a response similar to herbicide efficiency for all luminosity conditions; thus, the levels of injury varied increasingly with the increase of the herbicide dose.

However, when evaluating the $\mathrm{GR}_{50}$ and $\mathrm{GR}_{80}$ values of plant regrowth, it was possible to observe a reduction in plants that remained $72 \mathrm{~h}$ in the dark. The values of $\mathrm{GR}_{50}$ and $G \mathrm{R}_{80}$ were approximately 36 and $28 \%$ lower when compared to the respective values of application in the daytime period (Table 1). This reduction may be related to the increased absorption of the product. The amount of the product that reached the site of action (EPSPS enzyme, located in chloroplasts) at the end of the evaluation at 28 DAA at doses of $720,1,440$, and $2,160 \mathrm{~g} \mathrm{ha}^{-1}$ was sufficient to promote efficient control of $U$. brizantha plants for any light exposure condition. Because in conditions of greater availability of light, glyphosate is less absorbed by $U$. brizantha; however, the product is more translocated (MOTA et al., 2020).

The reduction in the percentage of plant control between the five treatments at the end of the 28 DAA may have been because all plants were taken back into the open under normal lighting conditions until the end of the evaluations. It is plausible that, as in the study conducted by Dias Filho (2002), U. brizantha plants reduced their photosynthetic capacity under shade. However, considering that plants can alter their 
biochemical, physiological, and morphological characteristics in response to environmental variation (SCHLICHTING, 1986), it is possible that, in this study, U. brizantha plants when exposed to sunlight after the period of exposure to shade, returned to photosynthesizing at normal rates, resulting in similar responses to the herbicide among treatments over time.

Table 1: Estimates of the parameters of the regression equations for the control and dry matter of Urochloa brizantha cv.Marandu submitted to glyphosate application in different availability of sunlight with daytime, night application and followed by 24,48 or $72 \mathrm{~h}$ of dark, with evaluation 30 days after cutting (regrowth).

\begin{tabular}{|c|c|c|c|c|c|c|c|c|c|}
\hline \multirow{2}{*}{ Treatment } & & \multicolumn{8}{|l|}{ Control } \\
\hline & & $a$ & $b$ & $\mathrm{C}$ & $d$ & $C_{50}$ & $\mathrm{C}_{80}$ & $\mathrm{R}^{2}$ & $p$ value \\
\hline \multirow{5}{*}{7 DAA } & Night & 77.43 & 141.47 & -1.07 & -- & 247.94 & $>2,160$ & 0.98 & 0.0004 \\
\hline & Daytime & 73.77 & 209.79 & -1.57 & -- & 336.88 & $>2,160$ & 0.99 & $<0.0001$ \\
\hline & $24 \mathrm{~h}$ & 68.47 & 329.95 & -0.91 & -- & 985.66 & $>2,160$ & 0.99 & $<0.0001$ \\
\hline & $48 \mathrm{~h}$ & 54.20 & 283.80 & -1.26 & -- & $2,026.56$ & $>2,160$ & 0.98 & 0.0004 \\
\hline & $72 \mathrm{~h}$ & 48.64 & 737.75 & -0.71 & -- & $>2,160$ & $>2,160$ & 0.99 & 0.0056 \\
\hline \multirow{5}{*}{14 DAA } & Night & 109.20 & 264.98 & -1.00 & -- & 223.80 & 725.97 & 0.99 & $<0.0001$ \\
\hline & Daytime & 107.50 & 366.85 & -1.02 & -- & 319.88 & 1045.09 & 0.99 & 0.0002 \\
\hline & $24 \mathrm{~h}$ & 93.06 & 306.58 & -1.29 & -- & 344.23 & 1249.50 & 0.99 & $<0.0001$ \\
\hline & $48 \mathrm{~h}$ & 80.56 & 294.40 & -1.31 & -- & 428.70 & $>2,160$ & 0.99 & $<0.0001$ \\
\hline & $72 \mathrm{~h}$ & 96.57 & 532.98 & -1.03 & -- & 571.05 & $>2,160$ & 0.99 & 0.0008 \\
\hline \multirow{5}{*}{21 DAA } & Night & 109.18 & 268.62 & -1.23 & -- & 234.22 & 609.87 & 0.99 & $<0.0001$ \\
\hline & Daytime & 105.04 & 281.97 & -1.45 & -- & 263.90 & 628.21 & 0.99 & $<0.0001$ \\
\hline & $24 \mathrm{~h}$ & 100.20 & 253.15 & -1.75 & -- & 252.57 & 555.83 & 0.99 & $<0.0001$ \\
\hline & $48 \mathrm{~h}$ & 100.35 & 279.55 & -1.55 & -- & 278.29 & 676.12 & 0.99 & $<0.0001$ \\
\hline & $72 \mathrm{~h}$ & 106.90 & 387.72 & -1.35 & -- & 352.32 & 869.24 & 0.99 & $<0.0001$ \\
\hline \multirow{5}{*}{28 DAA } & Night & 105.93 & 242.68 & -1.52 & -- & 225.43 & 509.25 & 0.99 & $<0.0001$ \\
\hline & Daytime & 103.64 & 235.10 & -1.78 & -- & 226.00 & 466.33 & 0.99 & $<0.0001$ \\
\hline & $24 \mathrm{~h}$ & 100.98 & 225.14 & -1.91 & -- & 222.86 & 453.72 & 0.99 & $<0.0001$ \\
\hline & $48 \mathrm{~h}$ & 105.75 & 248.49 & -1.51 & -- & 231.21 & 526.43 & 0.99 & $<0.0001$ \\
\hline & $72 \mathrm{~h}$ & 111.24 & 323.73 & -1.31 & -- & 277.30 & 663.62 & 0.98 & 0.0002 \\
\hline \multirow{2}{*}{ Treatment } & & \multicolumn{8}{|c|}{ Dry matter } \\
\hline & & $a$ & $b$ & $\mathrm{C}$ & $d$ & $\mathrm{GR}_{50}$ & $\mathrm{GR}_{80}$ & $\mathrm{R}^{2}$ & $p$ value \\
\hline \multirow{5}{*}{ Regrowth } & Night & -3.04 & 97.95 & 269.57 & -2.38 & 289.09 & 554.67 & 0.99 & 0.0001 \\
\hline & Daytime & -0.72 & 100.27 & 317.82 & -3.61 & 319.88 & 470.73 & 0.99 & $<0.0001$ \\
\hline & $24 \mathrm{~h}$ & -0.31 & 98.58 & 235.66 & -3.89 & 238.18 & 344.82 & 0.99 & $<0.0001$ \\
\hline & $48 \mathrm{~h}$ & -3.81 & 99.02 & 235.91 & -1.88 & 258.81 & 584.77 & 0.99 & 0.0001 \\
\hline & $72 \mathrm{~h}$ & -1.23 & 97.28 & 194.52 & -2.97 & 201.63 & 335.80 & 0.99 & 0.0001 \\
\hline
\end{tabular}

\section{CONCLUSIONS}

The species Urochloa brizantha cv.Marandu was efficiently controlled by glyphosate from the dose of 1,440 $\mathrm{g} \mathrm{ha}^{-1}$ with day-time applications, nighttime applications, or applications followed by 24,48 , or $72 \mathrm{~h}$ of darkness. Still, due to the differences observed in plant control up to 21 days after application (DAA) and in the reduction of regrowth, the amount of light received by the plants favors the behavior of glyphosate.

Therefore, it is not possible to safely recommend to producers that they apply this herbicide at night for the control of $U$. brizantha. Considering that there may have been changes in the absorption and translocation of the herbicide by the influence of light, it is still necessary to analyze these factors to better understand the behavior of glyphosate in plants and to make safer recommendations regarding the time of application.

ACKNOWLEDGEMENTS: We would like to thank the financial support of the Conselho Nacional de Desenvolvimento Científico e Tecnológico (CNPq) and Coordenação de Aperfeiçoamento de Pessoal de Nível Superior (CAPES). 


\section{REFERENCES}

ALMEIDA, D. P.; FERREIRA, M. D. C.; SANTOS, R. T. D. S.; GRIESANG, F.; SANTOS, E. D. S. D.; TIMOSSI, P. C.. Influence of glyphosate concentrations on spray solution physicochemical characteristics and drift potential. Engenharia Agrícola, v.40, n.1, p.69-77, 2020.

BORGHI, E.; COSTA, N. V.; CRUSCIOL, C. A. C.; MATEUS, G. P. Influência da distribuição espacial do milho e da Brachiaria brizantha consorciados sobre a população de plantas daninhas em sistema plantio direto na palha. Planta Daninha, v.26, n.3, p.559-568, 2008.

CAMPOS, C. F.; VITORINO, H. S.; SOUZA, G. S. F.; SANTANA, D. C.; MARTINS, D.. Translocação dos herbicidas glyphosate e imazamox em plantas de aguapé. Arquivos do Instituto Biológico, v.80, n.2, p.177-182, 2013.

CARVALHO, S. J. P.; LOMBARDI, B. P.; NICOLAI, M.; LÓPEZOVEJERO, R. F.; CHRISTOFFOLETI, P. J.; MEDEIROS, D.. Curvas de dose-resposta para avaliação do controle de fluxos de emergência de plantas daninhas pelo herbicida imazapic. Planta Daninha, v.23, n.3, p.535-542, 2005.

CASTRO, E. B.; CARBONARI, C. A.; VELINI, E. D.; BELAPART, D.; GOMES, G. L. G. C.; BEN, R.. Absorption, translocation and metabolic effects of glyphosate by Eucalyptus plants. Scientia Forestalis, n.111, p.719-727, 2016.

CATANEO, A. C.; DÉSTRO, G. F. G.; FERREIRA, L. C.; CHAMMA, K. L.; SOUSA, D. C. F.. Glutathione S-transferase activity on the degradation of the herbicide glyphosate in maize (Zea mays) plants. Planta Daninha, v.21, n.2, p.307-312, 2003.

CIESLIK, L. F.; VIDAL, R. A.; TREZZI, M. M.. Fatores ambientais que afetam a eficácia de herbicidas inibidores da ACCase: Revisão. Planta Daninha, v.31, n.2, p.483-489, 2013.

CONCENÇO, G.; FERREIRA, E. A.; FERREIRA, F. A.; SANTOS, J. B.. Plasmodesmos: transporte simplástico de herbicidas na planta. Planta Daninha, v.25, n.2, p.423-432, 2007.

DELLA-CIOPPA, G.; BAUER, S. C.; KLEIN, B. K.; SHAH, D. M.; FRALEY, R. T.; KISHORE, G. M.. Translocation of the precursor of 5-enolpyruvylshikimate-3-phosphate synthase into chloroplasts of higher plants in vitro. Proceedings of the National Academy of Sciences, v.83, n.18, p.6873-6877, 1986.

DIAS FILHO, M. B.. Photosynthetic light response of the C4 grasses Brachiaria brizantha and B. humidicola under shade. Scientia Agricola, v.59, n.1, p.65-68, 2002.

FREITAS, F. C. L.; FERREIRA, L. R.; FERREIRA, F. A.; SANTOS, M. V.; AGNES, E. L.; CARDOSO, A. A.; JAKELAITIS, A.. Formação de pastagem via consórcio de Brachiaria brizantha com o milho para silagem no sistema de plantio direto. Planta Daninha, v.23, n.1, p.49-58, 2005.

MARCHI, G.; MARCHI, E. C. S.; GUIMARÃES, T. G.. Herbicidas: mecanismos de ação e uso. Embrapa Cerrados-Documentos (INFOTECA-E), 2008.

MARTINS, D.; CARBONARI, C. A.; TERRA, M. A.; MARCHI, S. R.. The effect of adjuvants on glyphosate absorption and translocation in water hyacinth (Eichhornia crassipes). Planta Daninha, v.27, n.1, p.155-163, 2009.

MARTINSON, K. B.; SOTHERN, R. B.; KOUKKARI, W. L.; DURGAN, B. R.; GUNSOLUS, J. L.. Circadian response of annual weeds to glyphosate and glufosinate. Chronobiology International, v.19, n.2, p.405-422, 2002.

MOHR, K.; SELLERS, B. A.; SMEDA, R. J.. Application time of day influences glyphosate efficacy. Weed Technology, p.7$13,2007$.

MOTA, L. M.; MENDES, K. F.; JÚNIOR, L. H. B.; SILVA, E. M. G.; FURTADO, I. F.; TORNISIELO, V. L.. Light availability interferes with absorption and translocation of $14 \mathrm{C}$ glyphosate in Urochloa brizantha cv.Marandu plants. Journal of Radioanalytical and Nuclear Chemistry, v.326, n.1, p.683693, 2020.

PETERSON, D. E.; THOMPSON, C. R.; REGEHR, D. L.; ALKHATIB, K.. Herbicide mode of action. Topeka: Kansas State University, 2001

$R$ CORE TEAM. A language and environment for statistical computing. Vienna: R Foundation for Statistical Computing, 2019.

ROMAN, E. S.; BECKIE, H.; VARGAS, L.; HALL, L.; RIZZARDI, M.; WOLF, T. M.. Como Funcionam os Herbicidas. Passo Fundo: Berthier, 2007.

SANTOS JUNIOR, A.; TUFFI SANTOS, L. D.; COSTA, G. A.; BARBOSA, E. A.; LEITE, G. L. D.; MACHADO, V. D.; CRUZ, L. R.. Manejo de tiririca e trapoeraba com glyphosate em ambientes sombreados. Planta Daninha, v.31, n.1, p.213221, 2013.

SATCHIVI, N. M.; WAX, L. M.; STOLLER, E. W.; BRISKIN, D. P.. Absorption and translocation of glyphosate isopropylamine and trimethylsulfonium salts in Abutilon theophrasti and Setaria faberi. Weed Science, v.48, n.6, p.675-679, 2000.

SBCPD. Sociedade Brasileira da Ciência das Plantas Planinhas. Procedimentos para instalação, avaliação e análise de experimentos com herbicidas. Londrina: SBCPD, 1995.

SCHLICHTING, C. D.. The evolution of phenotypic plasticity in plants. Annual Review of Ecology and Systematics, v.17, n.1, p.667-693, 1986

SEEFELDT, S. S.; JENSEN, J. E.; FUERST, E. P.. Log-logistic analysis of herbicide dose-response relationships. Weed Technology, p.218-227, 1995.

SILVA, U. R.; TIMOSSI, P. C.; ALMEIDA, D. P.; LIMA, S. F.. Eficácia do glyphosate na dessecação de espécies de Urochloa. Revista Brasileira de Herbicidas, v.12, n.2, p.202209, 2013.

STREIBIG, J. C.. Herbicide bioassay. Weed Research, v.28, n.6, p.479-484, 1988.

VIDAL, R. A.; PAGNONCELLI JUNIOR, F.; FIPKE, M. V.; QUEIROZ, A. R. S.; BITTENCOURT, H. V. H.; TREZZI, M. M.. 
Fatores ambientais que afetam a eficácia de glifosato:

Síntese do conhecimento. Pesticidas: Revista de

Ecotoxicologia e Meio Ambiente, v.24, 2014.
WALTZ, A. L.; MARTIN, A. R.; ROETH, F. W.; LINDQUIST, J. L.. Glyphosate efficacy on velvetleaf varies with application time of day1. Weed Technology, v.18, n.4, p.931-939, 2004.

A CBPC - Companhia Brasileira de Produção Científica (CNPJ: 11.221.422/0001-03) detém os direitos materiais desta publicação. Os direitos referem-se à publicação do trabalho em qualquer parte do mundo, incluindo os direitos às renovações, expansões e disseminações da contribuição, bem como outros direitos subsidiários. Todos os trabalhos publicados eletronicamente poderão posteriormente ser publicados em coletâneas impressas sob coordenação da Sustenere Publishing, da Companhia Brasileira de Produção Científica e seus parceiros autorizados. Os (as) autores (as) preservam os direitos autorais, mas não têm permissão para a publicação da contribuição em outro meio, impresso ou digital, em português ou em tradução. 